UDC $910+81 ’ 255$

DOI: https://doi.org/10.18485/iipe_ria.2021.72.1182.4

Biblid 0543-3657, 72 (2021)

Vol. LXXII, No. 1182, pp. 67-81

Review article

\title{
TRANSLATIONS OF GEOGRAPHY: REPRESENTATIONS OF SPACE AND CULTURE IN LITERARY TEXT ANALYSIS
}

\author{
Ilias G. SPYRIDONİDIS ${ }^{1}$
}

\begin{abstract}
In recent years, the analysis of geographic, cultural, and semiotic spaces has gradually piqued the interest of researchers, particularly those involved in interdisciplinary projects in the fields of translation and cultural studies. But, what exactly do we mean when we argue about the translation of geography in terms of the perception and interpretation of space, real or imaginary? And how could literary text analysis offer qualitative and quantitative data in order to represent spaces and cultures and, finally, translate the geocultural coordinates of an area? The purpose of this article is to first identify the characteristics of modern translations of geography, and then to present a geocultural approach to literary text analysis that can reconstruct either geographic or semiotic and cultural space.

Keywords: translation, geography, space, imaginary, real, text analysis, literature, geocultural approach, semiotic and cultural diversity
\end{abstract}

\section{GEOGRAPHY OF TRANSLATION AND TRANSLATION OF GEOGRAPHY}

Indisputably, the last two decades have witnessed the beginning of a prolific dialogue between translation and geography. Such a dialogue is continuously expanding and developing within an interdisciplinary framework. Recently, Federico Italiano (2016: ix) has stated that there is an "increasing attention paid by translation scholars towards a spatial understanding of translation". Federico Italiano considers this increasing interest in geography shown by some translation scholars as a "spatial turn" in translation studies. Regarding this tendency, Italiano underlines that:

\footnotetext{
${ }^{1}$ Translation and Geocultural Relations Researcher, Department of Italian Language and Literature, Faculty of Philosophy, Aristotle University of Thessaloniki, Greece.

E-mail: spyridin@hotmail.com.
} 
The "spatial turn" within the recent flourishing of the "translational turn" is not merely another academic trend but probably the most consistent attempt to overcome the almost positivistic view of translation based on the illusion of linguistic equivalence in the transfer of meaning (2016: ix).

There is also no doubt that the Geography of Translation does not constitute an alternative lexical form or a linguistic sign or a simple synonym for the Translation of Geography. In order to avoid misunderstandings regarding the dialogue between Translation and Geography, we must highlight the fact that Translation and Geography constitute an interdisciplinary subfield of Translation Studies with the contribution of Geography, Semiotics and Cultural Studies. Translation and Geography principally consist of two different areas of study: the Geography of Translation and the Translation of Geography. On the one hand, the Geography of Translation concerns the study of translation as a cultural product on a geographical scale: the translators, the editorial centers, the cities and the schools where translation is produced, the distribution networks, the consumption systems and societies, the imports and exports of translations in the literary systems, when, where and under what circumstances translations are born or consumed, etc. As far as the Hellenic geographic space and the Greek literature system in relation to the Italian literary system are concerned, the monograph of Zosi Zografidou (1999) is representative, especially, of the $20^{\text {th }}$ century ItalianGreek translation production. Another monograph (Spyridonidis 2017), based on $\mathrm{PhD}$ research under the supervision of the professor of Translation Studies, Eleni Kassapi, presents a case study of a delimited geographic space of a city, in which we studied the Italian cultural influence of the translations in Kozani's library from the $15^{\text {th }}$ century to 1912 (during the Ottoman occupation) (Spyridonidis 2012). This case study was carried out from a diachronic perspective. Recently, postdoctoral research gave us the opportunity to study the geography of translations at a regional level, analyzing the corpora of the public libraries in Western Macedonia. (Spiridonidis 2021). The importance of geography and cartography in literature was also clearly expressed by Franco Moretti in his introduction "towards a geography of literature" in Atlas of the European novel 1800-1900:

"... geography is not an inert container, it is not a box in which history 'happens', but an active force that pervades the literary field and shapes it in depth. Making the connection between geography and literature explicit, then - mapping it: because a map is precisely that, a connection made visible - will allow us to see some significant relationships that have so far escaped us" (Moretti 1998, 3).

"Such a literary geography, however, can refer to two very different things. It may indicate the study of space in literature; or else, of literature in space. In the first case, the dominant is a fictional one: Balzac's version of Paris, the Africa of colonial romances, Austen's redrawing of Britain. In the second case, 
it is a real historical space: the provincial libraries of Victorian Britain, or the European diffusion of Don Quixote and Buddenbrooks" (Moretti 1998, 3).

On the other hand, the Translation of Geography principally concerns the study of the representation of space and culture within literary texts. In other words, how geography and space are translated and interpreted from one semiotic code to another. Besides, Federico Italiano offers another important aspect of the Translation of Geography:

"Rather, I am interested in the translation of geographies; that is, a negotiation of cultural differences between constructions of worlds and spatial imaginations. Consequently, the questions raised in my book primarily concern how and to what extent Western spatial imaginations, in particular those constructed by literary works, have been translated across languages, media and epochs" (Italiano 2016, 4).

Without a doubt, the concept of space and the spatial imaginary are fundamental and central to the translation of geography. That is also confirmed by the above-mentioned Italian scholar when he writes:

"I invariably came to the conclusion that the spatial imagination contained in a work of literature was the most truthful mirror in which humanity could reflect and examine itself. Inevitably, spurred on by my own experience of orientation in space as a form of translation across cultural differences, I started to ask myself how spatial imaginations negotiate geographies not only across epochs, languages and literary texts, but also across the media..." (Italiano 2016, ix).

Taking into consideration all the above, we realize that a geocultural space, real or imaginary, can take the form of a prototype literary text through the work of a writer. Consequently, that space included in a prototype can also be translated into other languages or other semiotic systems. The diffusion and the reception of this particular perception of space (that derives from the writer's personal point of view, more or less impartial) can also be measured in terms of the knowledge effect on the readers or as a mere information-data shared on a local, regional or global scale. In addition, the Translation of Geography and the geocultural approach to literary texts' analysis can practically provide significant data, information and documentation about the perception, the interpretation and the representation of a specific area from a diachronic or a synchronic perspective within the study of different texts. In other terms, how has a specific area been seen or translated by various authors and in various literary texts, prototypes and translations? Furthermore, what differences and what similarities can we discover through a critical analysis of these different texts?

In this article, we present the way in which we can extract geographic and cultural information from literary texts after the implementation of a geocultural 
approach to literary text analysis. This method allows us to collect data that could contribute to the increase and broadening of our knowledge in many fields related - directly or indirectly - to geographic space. Such fields are antiquities, architecture, nature, history, health, population, economic life, production-techniques, cultural life, religion, political structures, travel conditions, etc.

Moreover, the Translation of Geography, in its modern concept, is also considered an inherent part of the Geopolitics of Translation. According to Ioannis Mazis $(2002,514)$, translations form "the geopolitics of translation in the service of wider civilizations' geopolitics" and constitute important geopolitical factors such as the possession of knowledge and information. Mazis also writes that "As it turns out, we are now referring to 'geopolitics of culture' or, more precisely, to 'geopolitics of civilizations"' (2002, 515). Michael Cronin also highlighted some aspects of translation in relation to the geopolitics of the globalized world in his monographs Across the Lines (2000), Translation and Globalization (2003) and Translation and Identity (2006).

\section{GEOCULTURAL APPROACH AND LITERARY TEXT ANALYSIS}

It is interesting how varying interpretations of a specific space are inspired by diverging points of view, different cultures and perspectives. So, how is the geography of an area in a text or at least some significant geocultural elements of a specific space perceived and represented? In order to study and analyze texts, we must first compile a text corpus and determine the variables for our research. For example, within the framework of the Apollonis research project (Apollonis n.d.), which is part of the Clarin:el project - the National Infrastructure for Language Resources \& Technologies in Greece (Clarin:el n.d.), and is run at the Aristotle University of Thessaloniki under the scientific supervision of Professor Titika Dimitroulia (Department of French Language and Literature), we studied the travelogues' translations from Italian into Greek from a diachronic perspective. As a result, we created a corpus of texts containing all the translations of Italian travelogues into Greek. We continued with the implementation of text analysis using a geocultural approach in order to extract data and information about specific spatial categories of language signs, such as toponyms or realia. In parallel with our geocultural text analysis, we annotated the texts in order to create an annotated language resource. In fact, the annotation of the translated texts enabled us to collect significant geocultural spatial data. It is a matter of fact that toponyms, as language and semiotic signs, constitute fundamental elements of the representation of an area. On the other hand, toponyms also constitute a part of the spatial coordinates of literary texts. After a comparative analysis of the annotated texts, it is interesting, indeed, to discover the differences that emerge between some specific travelogue translations when describing a particular space, area or region. 
In some cases, the translations of the geographical aspects of the same space were very common among the various travelogues, which were written, more or less, in the same chronological period. So, what is characteristic is the similarity between interpretations and translations of space. This similarity emerges from different travelogues which, in the same period, describe a specific space. An indicative example constitutes the description of Thessaloniki in three different texts written by Ciriaco di Ancona in 1431, Pero Tafur in 1436 and Giovanni Maria Angiolello in 1470. Of course, we could never sustain that the translations of space that emerge from the above texts were identical. Nevertheless, it is a matter of fact that all these texts contain useful information about the translation of Thessaloniki's space. Furthermore, it was not only the representations of Thessaloniki's space in these particular literary texts that were quite similar, but also the interpretations of reality by their single writers. In 1431, a few months after the fall of Thessaloniki to the Ottomans, Ciriaco di Ancona or Ciriaco Anconitanus dei Pizzecolli described the city center, underlying the presence of important monuments and, in particular, of the great church of Saint Demetrius, the protector of the city (Grigoriou and Hekimoglou 2008, 28). Pero Tafur, in his Andanças é viajes de Pero Tafur por diversas partes del mundo avidos (1435-1439), referred also to Thessaloniki, conquered by the Ottomans, as an important city for the Christian world. Some years later, in 1470, Giovanni Maria Angiolello also described Thessaloniki as an important economic center, giving in his text particular attention to the metropolitan church of Saint Demetrius (Grigoriou and Hekimoglou 2008, 31-33). Finally, these three travelogues depict the specific urban geography of Thessaloniki from 1431 to 1470 , having as a common denominator the principal position of Saint Demetrius and the commercial and Christian character of the city. Of course, the geocultural methodology for the study of translations, their textual analysis, the annotation techniques and the semiotic categorization of the translated terms, is of greater interest to language and translation scientists and will be presented in reviews specialized in translation studies.

In substance, the study and the analysis of literary texts could provide us with representations and translations of space and culture useful as primary data or, in other cases, as complementary information for the reconstruction of reality in determined geographic areas. The information contained, for example, in travelogues or generally in travel literature texts is, without a doubt, semantically very rich. We can categorize systematically the annotated language signs in semiotic systems in order to facilitate our qualitative analysis. The semiotic categories that we will create depend directly on the content of the text. We can have categories such as toponyms (villages, cities, mountains, rivers, etc.), religion (churches, monasteries, synagogues, mosques, etc.), communication (streets, trains, stations, bridges, etc.), ancient sites, population, etc. 
At this point, it is interesting to report the results of an indicative case study that offers us useful qualitative and quantitative information and data in order to reconstruct the geography of southern Serbian territories in the late 16th century. We studied Paolo's Contarini text written in Italian in 1580, entitled "Diario del viaggio da Venezia a Constantinopoli di M. Paolo Contarini che andava bailo a per la repubblica veneta alla porta ottomana". The monograph was first published by Teresa Gattei in Venice in 1856. Paolo Contarini was born in Venice on 23th January 1529. He was the son of Dionisio Contarini and Fiordalise di Piero Zen. ${ }^{2}$ Paolo Contarini studied close to Paolo Manuzio and after his studies he began his political career as a "savio agli Ordini" and a major in Levante, respectively in 1555 and in 1557. In 1570, he was "provveditore", alias the governor of Zante. His role was also very important in the victory of the Christian powers in the battle of Lepanto. He was elected bailo of Constantinopoli in 1580, a position he held for three years, until 1583. According to Gaetano Cozzi in Diæionario Biografico degli Italiani $(1983,8)$ from Paolo Contarini's literal activity remained his diary, a rapid description of spaces, people, foods, caravanserais, mosques, cultivations, etc.:

"Quanto rimane di attività letteraria dei .C. non è, malgrado l'insegnamento manuziano, una prosa latina, ma un testo volgare, il Diario del viaggio da Venezia a Costantinopoli nel 1580 (edito da V. Lazari a Venezia nel 1856). Ł̀ una descrizione rapida fatta da un viaggiatore curioso ed attento, che ha saputo osservare quanto si proponeva al suo sguardo - il paesaggio, la gente, i cibi, i caravanserragli, le moschee, le coltivazioni, e così via - e sa ora raccontare, in modo serrato ed avvincente". ${ }^{3}$

In order to extract valuable geographic information and data from the diary text of Contarini, we first studied its content and, afterwards, we transcribed and annotated an indicative part. The transcribed and annotated part comes from the only known existing publication from 1856. The publication of the opera was dedicated to Marco Antonio Grimani by Girolamo Oliviero (1856, 5-6). There is also an introduction entitled "Avvertimento" that was written by V. Lazari. Paolo Contarini departed from Venice on 12th April 1580 and, after some days, arrived in Ragusa. Contarini started his journey to Constantinople from Ragusa's port. In the text that we transcribed, we annotated the semiotic category of the toponyms, firstly underlying the terms in the text and secondly, identifying and documenting

\footnotetext{
${ }^{2}$ More information on Paolo Contarini can be found at: Treccani n.d.

${ }^{3}$ The translation into English: [What remains of the literary activity of Contarini, despite the Manutian teaching, it is not a Latin prose, but a vulgar text, the Diary of the voyage from Venice to Constantinople in 1580 (published by V. Lazari in Venice in 1856). It is a quick description made by a curious and attentive traveler, who was able to observe what was proposed to his eyes - the landscape, the people, the foods, the caravanserai, the mosques, the crops, and so on - and now knows how to tell all these things, in a tight and compelling way].
} 
them. The semiotic category of toponyms includes not only names of cities or villages, but also names of rivers (hydronyms), mountains, planes, hills, etc. Practically, we analyse and annotate every space-specific term.

As we have already mentioned, Contarini started his voyage from Dubrovnik (Ragusa) (Contarini 1856, 13-20): "ed entrati in Ragusi per una porta, ne uscimmo per l'altra". After that, Contarini said (1856, 13-14): "1' alpe del Moncenisio di Francia e 1' Apennino" and then "vicini ad una bella fiumaja detta Tribina, presso ad una villa di Gomiliani". The next day, the diplomatic mission passed from "per una pianura lungo il detto fiume fino al ponte di Trebina, di Mehemet Bassà" "provincia di Cherzegò" arriving at "ascendendo e poi di scendendo un monte Innutoglam, ed alloggiammo la sera (che fu alli 13) in campagna ad una villa detta Mausco". The journey continued the following day (Contarini 1856, 13-14): "venimmo a trovar 1' origine del fiume sopraddetto chiamato Tribina, e venimmo alla valle di Bellichia, villa ov' è il caravanserà di Assan Bei", and then "fino ad una villa detta Trinova ove sono due caravanserà di poca importanza" they departed from Trinova and arrive in Cernizza. "Partimmo da Trinova e, cavalcando per luoghi assai aspri, venimmo a Cernizza", where they stopped to eat "Desinammo a Cernizza". In this part of the text, Contarini also referred to toponyms which did not constitute the stations of the diplomatic mission itinerary (1856, 14-15): "Narenta, Cherzegò, Persia, Zighet, Ungheria". The journey continued from Cernizza area to Termovaluca (Contarini 1856, 15-16): "Cernizza è più bassa, ed accanto le è un fiume detto Dobu", "venimmo alla costiera del monte ad alloggiare in campagna a Lazaricchia ovvero Casco", "un fiume detto Innoi", "Montammo di poi la montagna Camerdaglaion", "fin alla villa detta Ternovaluca", "vicino ad una fiumaja detta di Ternovaluca". The next day, the diplomatic mission arrived at (Contarini 1856, 15-16): "caravanserà di Temista, grande e molto onorevole. Continuammo dopo desinare il viaggio sempre per colline fino a Prisnovaluca accanto il fiume Drino", "mandammo a Fochia a pigliar del vino", "La fiumaja è molto bella e rapida, a similitudine della Piave, ed il suo principio è a Ternovaluca". Contarini mentioned many toponyms of the area and often described their basic characteristics. He took notes of everything that could be interesting to his diplomatic mission from Venice to Constantinople. Because of that, his text constitutes an extraordinary font of translation geography. Some other indicative toponyms that Contarini notes in his text are (1856, 17-20): "Caiut, caravanserà di Bracha, Plevia, fiume Brenopesnizza, Prepaglia dalli Calogeri di santo Saba, Novopazar, fiume Lino, un torrente detto Miles per paese poco coltivato, al monastero de' Calogeri di santo Saba, al castello Milesenas, il fiume Miles, luogo detto Milesenadraga, campagna detta Sinisfa, villa detta Dumaizza, torrente detto Rasca", etc. 
In our analysis, we create concordance table (Table 1) in order to better understand the context of the toponyms. As an indicative example, we studied the concordances of two toponyms and of a hydronym: "Plevia", "Prepaglia" and "Lino".

Table 1: Concordance table of some indicative toponyms in Paolo Contarini's itinerary from Venice to Constantinople in 1580.

\begin{tabular}{|l|l|l|l|}
\hline $\begin{array}{l}\text { Toponyms } \\
\text { in the prototype }\end{array}$ & $\begin{array}{l}\text { Concordances } \\
\text { in the prototype }\end{array}$ & Identification & Documentation \\
\hline Plevia & $\begin{array}{l}\text { procedemmo lasciando le } \\
\text { some a buonora a Plevia; } \\
\text { passata la campagnuola } \\
\text { vicina alla terra di Plevia, } \\
\text { ascendemmo una montagna } \\
\text { fredda e inculta }\end{array}$ & Pljevlja & $\begin{array}{l}\text { https://www.discover- } \\
\text { montenegro.com/pljevlja/ } \\
\text { https://en.wikipedia.org/ } \\
\text { wiki/Pljevlja }\end{array}$ \\
\hline Prepaglia & $\begin{array}{l}\text { fin a Prepaglia dalli Calogeri } \\
\text { di santo Saba; } \\
\text { però ci fermammo a } \\
\text { Prepaglia per far che le robe } \\
\text { passassero comodamente; } \\
\text { Prepaglia è assai buona villa }\end{array}$ & Prijepolje & SO RS 2014 \\
\hline Lino & $\begin{array}{l}\text { un torrente di poca } \\
\text { importanza che va nel Lino } \\
\text { fiume assai grande e molto } \\
\text { corrente; } \\
\text { venimmo al sopraddetto } \\
\text { fiume Lino }\end{array}$ & Lim & Itinari 2018 \\
\hline
\end{tabular}

The context is not only useful for the identification of the toponyms, but also for the translation of the space and the reconstruction of reality.

In this part of the journey, from Ragusa to Novi Pazar, we identified a number of toponyms that could constitute useful data for the reconstruction of the travel itinerary and for the representation of the area's geography. But a certain number of toponyms extracted could be confusing, such as Ungheria, Montesanto, Damasco or Danubio. These name identities as toponyms do not constitute part of the itinerary and, of course, are not useful for the realistic representation of those south western Serbian territories. At this stage, it is highly important to implement geocultural text analysis in order to classify the toponyms into two 
groups: on one hand, the toponyms that are only mentioned in the text but do not constitute part of the real itinerary (for example: Montesanto) and, on the other hand, the toponyms that document real places on the itinerary (for example: Prepaglia, which is identified with Prijepolije). After the implementation of the geocultural text analysis, all the toponyms that constitute part of the traveler's itinerary emerged. An analogue methodology was implemented for travelogues by Agathoklis Azelis and Ilia Chatzipanagioti in Verzeichnis von ortsnamen und unterkunftsangaben in reisebericbten des 16 und 17 jabrbunderts Über die sudliche Balkanbalbinsel und das östliche mittelmeer in 1993. Therefore, Azelis and Chatzipanagioti (1993) did not study Paolo Contarini's travelogue and this is the reason that we present it as an indicative case study in this article.

In our case, Paolo Contarini's text contains a significant number of toponyms. As a result of our analysis, we reconstructed the itinerary of his journey from Ragusa to Novi Pazar. The more significant toponyms that he passed through during his journey were: Ragusa, the river Tribina, Gomiliani, Trebina's bridge, mount Innutoglam, Mausco, valle di Bellichia, Cernizza, Narenta, Dobu, Lazaricchia, Casco, Innoi, mount Camerdaglaion, Ternovaluca, the river Ternovaluca, Temista, Prinsnovaluca, the river Drin, Fochia, Caiut, Bracha, Plevia, the river Brenospenizza, Prepaglia, Mileseva monastery, the Mileseva river, the river Lino, Milesndraga, Sinisfa, Dumaizza, the river Rasca, Novopazar, Glucanizza, Ibar, Zigoli, Copaono, Gerastiani, Toplizza, Sundinno, Innerno, Gherguri, Dragonani, Cliani, Suarsco, Gostisinei, Crelintzi, Morava, Nissa, Nissava, Cunonizza, Clissma, Pinor, Siridurica. The basic stations of Contarini's travel to Constantinople in the Serbian territories in 1580 were: Trebinje, Foča, Pljevlja, Prijepojie, Novi Pazar and Nis.

It is also important to identify the toponyms as works of the history of geography. For example, Prepaglia is, without doubt, Prijepolije. The river Lino is, of course, Lim, Cernizza is Crmnica, and Casco is identified with Gacko. In addition, the descriptions of Contarini allow us to reconstruct the geography of the areas that he visited via the geocultural text analysis. In this article, we present a small part of the textual analysis of Contarini's diary. On a larger scale, we can also precisely reconstruct the itinerary of his entire travel from Venice to Constantinople. Moreover, the above-presented geocultural text analysis can be implemented as a functional approach to every literary text which contains geographical information. The variable of the population is also important in the representation of a geographical area. Contarini offered interesting information about the population when he described that Serbians and Turks lived in separate areas (Contarini 1856, 17): "È partita la terra in due parti, in una abitano li turchi, vicino alla fiumaja, e nell' altra di sopra abitano li cristiani serviani di rito greco". According to Contarini, the population in Prijepolije was also divided into two communities $(1856,18)$ : "Prepaglia è assai buona villa, abitata per la metà da 
cristiani serviani di rito greco, e parte da turchi". Naturally, the Christians were all Serbs and in the churches the liturgy was celebrated in Serbian as the text documents (1856: 19): "vi sono tre cappelle che introducono d'una in altra; ufiziano nel rito greco in lingua serviana". Without a doubt, another variable that emerges from the travel diary is the food. Contarini described almost every day, not only the food that they found, but also the prices of the goods at every station. For example, outside Foča (Contarini 1856, 16): "Ci fornimmo di vino buono, pane negro ma assai sufficiente, castrati, ed ova, e desinammo fuor di Fochia a una fonte in campagna". In terms of prices, they discovered in Prijepojie (Contarini 1856, 17): “Trovammo focacce bianche, non lievite e mal cotte, ova a 14 all'aspro, latte e vino non buono, e portato da Ragusi e Narenta, avemmo pesce fresco della fiumaja, e salato grande del Danubio". Regarding the semiotic system of travel accommodation, there is a variety of terms that allow us to better understand how people travelled during the 16th century in the Ottoman-ruled territories. Contarini noted every day the places where they spent the night. In most cases, the places that they stopped at were caravanserais or other forms of guest houses. Contarini writes (1856, 20): "entrando poi in una campagna o valle lungo il fiume Rasca fino a Novobazar, ove alloggiammo tutto il giorno in un caravanserà coperto di coppi, grande, fatto dal sopraddetto Muthe Vilia".

What is also worth mentioning is a case study that is a part of the research at the Aristotle University in Thessaloniki. As a fairly impartial observer, Vico Mantegazza, an Italian traveler from Milan, described various parts of South East Europe in the last decades of the $19^{\text {th }}$ century and the first quarter of the $20^{\text {th }}$ century. In his journey through Macedonia in 1903, he described, among others, "Monastir (Bitola)", providing an extraordinary translation of the area at that time, dedicating to this city an entire chapter (VIII). In particular, Mantegazza described the street of the consuls in the city center (Mantegazza 1903, 244) and the

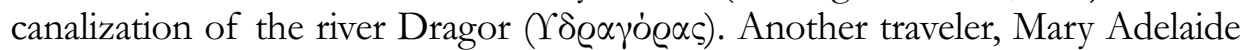
Walker, described the same location in 1864, some years before the canalization $(1864,156)$. In this direction, the collection of a corpus of translations from a specific place or area could possibly constitute a realistic representation of that space from a diachronic or synchronic perspective. Furthermore, another aspect that emerges from the text analysis and the translation of space is the qualitative and quantitative representation of the population. What seems to be interesting is the ethnic fragmentation of the population, in many cases, in South East Europe. In particular, in Monastir (Bitola), Vico Mantegazza described in his travel diary, not only the separate communities that constituted the population of the city (1903, 223-252), but also the differences in their activities (1903, 245-246) and life that were practically almost totally distinct. As an indicative example, Mantegazza depicted the fundamental characteristics of all the ethnic communities in Monastir that were surprisingly maintained as separate after approximately five centuries of 
Ottoman oppression. ${ }^{4}$ We can note that the literary texts with historical or geographical content can also constitute useful documentation for the analysis of communities' tensions.

The division and the fragmentation of the postmodern societies under the influence of globalization forces constitute a large scale phenomenon that is also represented not only in literary texts but also in informative ones. Recently, in some informative articles that appeared in Greek newspapers such as Eleftheros Typos, Athens Voice, and Ethnos, ${ }^{5}$ we read texts that translate the new geography of the city center of Athens, which has been transformed, in many cases, into Pakistani and Afghani controlled areas and how these fragmented realities create an environment of insecurity and regression at an economic, ${ }^{6}$ social and national level. ${ }^{7}$ In the same direction, some other indicative informative articles show how a hill called Strefi in Athens was transformed into an area of illegal activities controlled by an Algerian band (Propotas 2021). Over the last years, there has been a prolific publication, especially of informative texts, in almost every European language and literary system that tries to describe the fragmentation of space (particularly in cities) and the division of the communities. This attempt was attained by means of the translations of the new multicultural geography. There are surprising analogies between some translations of space in Madrid, Athens, Milan, Berlin, Paris and other European cities, presenting an image of homogenization when, at the same time, they are losing their cultural diversity. It is also worth analyzing this phenomenon by comparing textual translations of space.

Geographic space may be divided between two different communities, as it is a very well-known phenomenon, mostly evident in Israel. It is a matter of fact that the cohabitation of Israelis with Palestinian Arabs is a long and hard path, full of periods of tension and conflicts. However, the translation of space and geography in European cities has become more complicated, as has the problematic and conflictual cohabitation in many French, German, English, Spanish or Italian cities regarding a large number of ethnic, religious and cultural communities, creating

\footnotetext{
4 "Pei mestieri vi sono ancora a Monastir le corporazioni perfettamente chiuse -e ogni nazionalita ha la sua specialita. I Bulgari, per esempio, sono quelli che lavorano il rame; i Valacchi lavorano i metalli e sono esclusivamente opera loro tutte le impugnature damascate di fucili, di pugnali e gli oggetti di filigrana dei quali s'adornano specialmente le donne albanesi; e i Mussulmani hanno la specialita dei lavori di selleria. I Greci, non numerosi, hanno in mano il commercio," (Mantegazza 1903, 245).

${ }^{5}$ For some indicative informative text publications, see: Eleftheros Typos 2018; Triantafyllou 2019; Weekly News 2020; Asimakopoulos 2020; Ethnos 2020.

${ }^{6}$ An indicative study for the economic impact of the new geography of the city center of Athens could be seen at: HCH 2011.
}

${ }^{7}$ See at: SETE 2012. 
an iper-fragmented cultural geography and reality. It is a phenomenon of space separatism and fragmentation, especially in the degraded European suburbs. In this regard, also in modern Greek literature, there are texts that describe this new

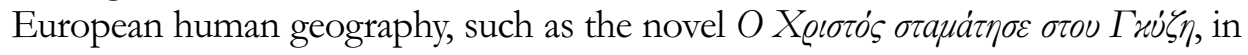
which Lefteris Panousis (2020) depicts the transformation of an area in the city center of Athens into a multicultural, fragmented space. Panousis uses a title that is semantically interesting and, at the same time, his novel constitutes an intertext with the Italian classic novel Cristo si è fermato a Eboli (Christ stopped at Eboli) by Carlo Levi (1945). The principal analogy that we found after studying and analyzing the two novels, the Italian and the Greek, is that the culture of Christian civilization did not arrive in Eboli because of the social and economic regression of the Lucania region until the 40s. At the same time, the Christian culture in Gyzi, Athens' city center, has been disappearing over the last two decades (2000-2020) due to a population synthesis change. Indeed, Panusis expressively talks about (2020, frontpage) "the death of a Greek neighborhood in the era of globalisation and Islamisation" in his novel's subtitle.

\section{CONCLUSION}

In conclusion, the interdisciplinary approach to the translation of geography is continuously developing over the last years. Within the framework of the Apollonis project at the Aristotle University of Thessaloniki, we studied, annotated and analyzed texts which were translated from Italian into Greek and which belonged to various periods and contained data for the representation of space, including the studied territory and period. Furthermore, it has been proven that the extraction of space information via geocultural literary text analysis is possible. Finally, this methodology could contribute to the further understanding of translation and of the perception of geographic space.

\section{REFERENCES}

Anconitanus dei Pizzecolli, Ciriaco. 2008. "Ciriaco Anconitanus dei Pizzecolli” in

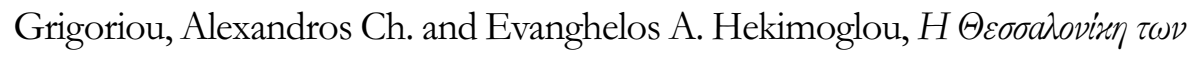
$\pi \varepsilon \varrho n \gamma \eta \tau \dot{\omega} v$ 1430-1930. Thessaloniki: Society for Macedonian Studies.

Angiolello, Giovanni Maria. 2008. "Giovanni Maria Angiolello" in Grigoriou,

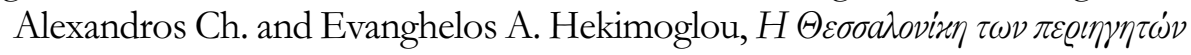
1430-1930. Thessaloniki: Society for Macedonian Studies.

Apollonis. n.d. "Apollonis project at Aristotle University 2014-5". Accessed 15

February 2021. http:/ /apollonis.frl.auth.gr/index.php/el/ 
Asimakopoulos, Costas. 2020. "Ethnos.gr journey to the triangle of the devil of Athens - Shocking testimonies", Ethnos, February 14. https://www.ethnos.gr/ ellada/88409_odoiporiko-toy-ethnosgr-sto-trigono-toy-diaboloy-tis-athinassokaristikes-martyries

Azelis, Agathoklis and Ilia Chatzipanagioti. 1993. "Verzeichnis von ortsnamen und unterkunftsangaben in reiseberichten des 16 und 17 jahrhunderts Über die

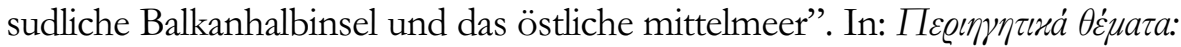

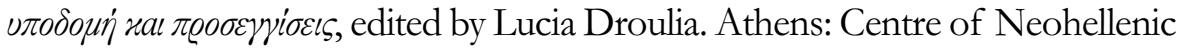
Researches National Hellenic Research Foundation, 157-319.

Clarin:el. n.d. "National Infrastructure for Language Resources \& Technologies". Accessed 15 February 2021. https://www.clarin.gr/en

Contarini, Paolo. 1856. Diario del viaggio da Venezia a Constantinopoli di M. Paolo Contarini che andava bailo a per la repubblica veneta alla porta ottomana nel 1580. Venezia: Teresa Gattei.

Cozzi, Gaetano. 1983. Lemma Paolo Contarini in Dizionario Biografico degli Italiani, Volume 28. https://www.treccani.it/enciclopedia/paolo-contarini_ (Dizionario-Biografico)/

Cronin, Michael. 2000. Across the lines: Travel, language, translation. Cork: Cork University Press.

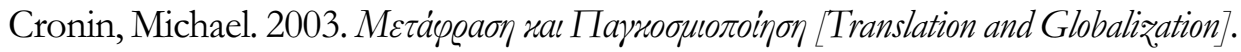
Athens: Diavlos.

Cronin, Michael. 2006. Translation and Identity, London \& New York: Routledge.

Eleftheros Typos. 2018. "The 7 'ghetto' areas of crime in Attica" September 3. https://eleftherostypos.gr/ellada/286479-oi-7-perioxes-gketo-tisegklimatikotitas-stin-attiki/

Ethnos. 2020. "These are the gangs that control the squares in the center of Athenshttps" February 14. https://www.ethnos.gr/ellada/88564_aytes-einaioi-symmories-poy-eleghoyn-tis-piatses-sto-kentro-tis-athinas

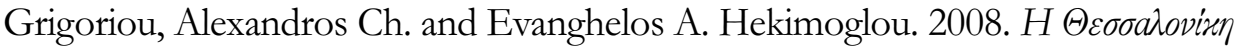

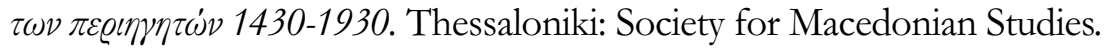

[HCH] Hellenic Chamber of Hotels. 2011. Ghettoization of part of the historic center of Athens and the consequences of the phenomenon on the economic life of the city. Accessed 15 February 2021. https://www.grhotels.gr/ gketopoiisi-tmimatos-tou-istorikou-kentrou-tis-athinas-kai-oi-synepeies-toufainomenou-stin-oikonomiki-zoi-tis-polis/

Italiano, Federico. 2016. Translation and Geography. New York: Routledge.

Itinari. 2018. "Lim River". Accessed 15 February 2021. https://www.itinari.com/ location/lim-river 
Levi, Carlo. 1945. Cristo si è fermato a Eboli. Torino: Einaudi.

Mantegazza, Vico. 1903. La Macedonia. Milano: Treves.

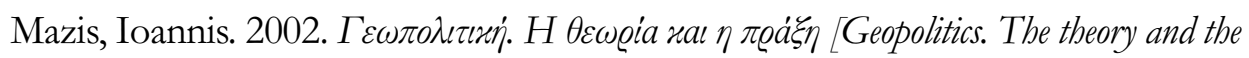
practice]. Athens: Papazisis.

Moretti, Franco. 1998. Atlas of the European novel 1800-1900. London \& New York: Verso.

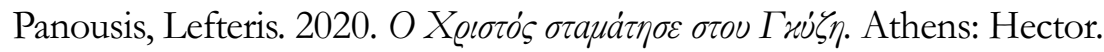

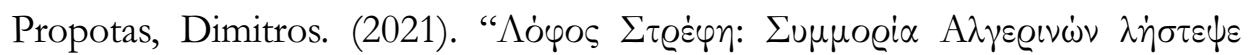

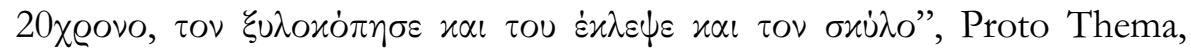
15/02/2021, https://www.protothema.gr/greece/article/1095360/summoriaalgerinon-listepse-20hrono-ton-xulokopise-kai-tou-eklepse-kai-ton-skulo/

[SETE] Greek Tourism Confederation. 2012. The Ghetto of the Center 'Kills' Athena, January 29. https://sete.gr/_fileuploads/entries/Daily\%20 Tourism\% 20Press/Old_entries/files/Media/12_Genika\%20Tourismos/120129Ethnos Kuriakis.pdf

[SO RS] Statistical Office of the Republic of Serbia. 2014. Comparative Overview of the Number of Population in 1948, 1953, 1961, 1971, 1981, 1991, 2002 and 2001, April 2014. https://pod2.stat.gov.rs/ObjavljenePublikacije/ Popis2011/Knjiga20.pdf

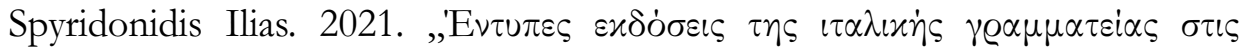

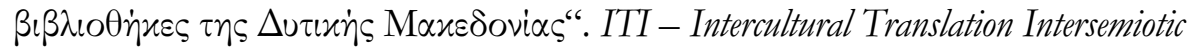
Journal 10 (1). DOI: https://doi.org/10.26262/iti.v10i1.7956

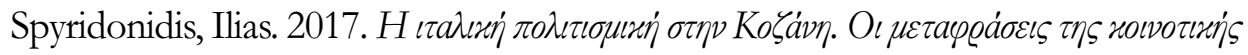

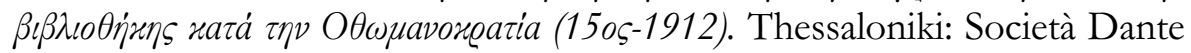
Alighieri di Salonicco.

Spyridonidis, Ilias. 2012. Italian cultural influence of the translations in Kozani's library from the $15^{\text {th }}$ century to 1912. Aristotle University of Thessaloniki. Faculty of Philosophy. Department of Italian Language and Literature. https://www.didaktorika.gr/eadd/handle/10442/31764.

Tafur, Pero. Andancas é viajes de Pero Tafur por diversas partes del mundo avidos (14351439), ed. Marcos Jiménez de la Espada, Madrid, Impr. de M. Ginesta, 1874.

Treccani. n.d. "Contarini, Paolo". Accessed 15 February 2021. https://www.treccani. it/enciclopedia/paolo-contarini_\%28Dizionario-Biografico\%29/

Triantafyllou, Soti. 2019. "How to decontaminate", Athens Voice, April 18. https://www.athensvoice.gr/politics/538337_pos-ginetai-i-apo-gketopoiisi

Walker, Mary Adelaide. (1864). Through Macedonia to the Albanian Lakes. London: Chapman and Hall. 
Weekly Nenss. 2020. "The immigrant ghettos in the center of Athens: How they have distributed the posts and how they act [infographic]" February 14. https://weeklynews.gr/ta-gketo-metanaston-sto-kentro-tis-athinas-posechoyn-moirasei-ta-posta-kai-pos-droyn-infographic/

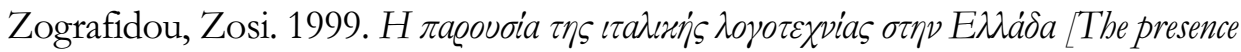
of the Italian literature in Greece]. Thessaloniki: Paratiritis.

\section{PREVODI GEOGRAFIJE: PREDSTAVLJANJA PROSTORA I KULTURE U ANALIZI KNJIŽEVNOG TEKSTA}

Apstrakt: Poslednjih godina analiza geografskih, kulturnih i semiotičkih prostora postepeno je pobudila interesovanje istraživača, posebno onih koji su uključeni u interdisciplinarne projekte na polju prevodilaštva i kulturoloških studija. Ali, na šta tačno mislimo kada se bavimo prevodom geografije u smislu percepcije i tumačenja prostora, stvarnog ili imaginarnog? Osim toga, kako bi analiza književnog teksta mogla ponuditi kvalitativne i kvantitativne podatke kako bi se predstavili prostori i kulture i, konačno, preveli geokulturne koordinate nekog područja? Svrha ovog članka je da prvo identifikuje karakteristike savremenih prevoda geografije, a zatim da predstavi geokulturni pristup analizi književnog teksta koji može rekonstruisati kako geografski, tako i semiotički i kulturni prostor. Kjučne reči: prevod, geografija, prostor, imaginarno, stvarno, analiza teksta, književnost, geokulturni pristup, semiotička i kulturna raznolikost.

Received: 21.05.2021

Accepted: 23.07.2021 